\title{
Investigating the inter-relationships \\ between beliefs, autonomy, and motivation in the context of foreign language learning/teaching
}

Maria Letícia Galizzi da Luz Moreira

Fábio Alves

Universidade Federal de Minas Gerais

\begin{abstract}
A pesquisa tratada no artigo tem como objetivo identificar as crenças de professores e alunos de inglês da rede escolar municipal de Belo Horizonte sobre cinco temas principais, a saber: a aptidão para a aprendizagem de línguas estrangeiras, o grau de dificuldade do idioma, a natureza da aprendizagem de línguas, as estratégias de aprendizagem e o grau de autonomia e motivação dos alunos. Os resultados obtidos nos permitiram verificar que as crenças de alunos e professores são relativamente semelhantes no que diz respeito à natureza e ao grau de dificuldade que a língua apresenta, à noção de aptidão para a aprendizagem de línguas e até mesmo em relação às estratégias de aprendizagem utilizadas em sala. No entanto, diferem consideravelmente no que se refere à visão que ambos têm do aluno.
\end{abstract}

This article aims at investigating the beliefs of teachers' and students' of English as a foreign language in the public school network of the city of Belo Horizonte, Brazil. The analysis focuses on five main topics, namely, aptitude to learn languages, the degree of difficulty of a particular language, the nature of learning languages in general, the learning strategies and the degree of autonomy and motivation of the students involved in the research. The results provide evidence that teachers' and students' beliefs are relatively similar as far as the nature and the degree of difficulty of English are concerned, as well as in relation to the notion of aptitude to learn languages and even in relation to the learning strategies used in the classroom. However, they differ considerably in the vision that both groups have of the student.

In Brazilian society education is seldom seen as a tool to help human beings become self-reflective and therefore autonomous. The state of affairs is such that in the field of foreign language teaching, many private schools seldom demand that teachers have experience in teaching. People who have lived abroad and can speak the language are hired even if they have precarious or no knowledge of pedagogy. And yet, once hired, there is usually little investment in their training. 
According to Paiva et al (1997, p. 167), in the Encontro Nacional sobre Políticas e Línguas Estrangeiras (National Meeting on Policies and Foreign Languages), participants came to the conclusion that

The lack of teachers and the lack of real skills among many of the teachers at work have made it impossible to meet the needs of our country in terms of efficient language learning; there is a continuous need to offer training programs to teachers so that they develop and reflect upon their own pedagogical work.

Still, we live in a capitalistic society, in which most schools aim at profit. Teachers' wages are generally so low that they do not make enough money to keep investing in their own professional growth. To add insult to injury, although 90\% of the doctoral theses written in Brazil in Applied Linguistics are related to foreign language teaching,

the theoretical and practical developments of the applied linguistics programs do not manage to go beyond the academic world to reach the relatively distant world of the classrooms, where teaching practice actually takes place. There is an imbalance between the theoretical development in Applied Linguistics and the low standards of foreign language education at schools (MOITA LOPES, 1996, p. 31).

As a result, the books adopted by schools serve many times as the methodological basis, with no awareness that the choice of a specific technique or method necessarily implies a previous conception of language and learning.

In the scenario presented above, classrooms are not usually a place where critical thinking is fostered. On the contrary, classrooms often work as a place where social rules are absorbed and reproduced within a clear distribution of power. It is usually an authoritarian classroom reproducing an authoritarian society. In this type of classroom, the teacher is usually in charge and the students follow the rules.

Any effort to change the current situation will certainly face resistance, not only from institutions and teachers accustomed to these stifling practices, but also from students who are not used to reflect about their own learning process. Therefore, the necessary change in the status quo demands an effort towards having all involved being aware of the values of our society and the roles each individual is expected to play. But, how can this be done?

Theoretical work produced in the 1990's has shown that the teacher is a central element in classroom processes. Therefore, by 
helping teachers become aware of their privileged role as educators, we expect that they will be able to help students become more critical and thus, more autonomous. We understand autonomy as a possible means to more social freedom. This autonomy depends largely on selfknowledge, such as an awareness of one's social environment.

We expect the research on beliefs here presented to contribute this by providing the basis for a broad reflection on four levels: students will become aware that some of their beliefs may be unfounded and others may be helpful to their learning process; teachers will become more aware of their own teaching practices; teachers and students will be conscious of each others' beliefs so that they can work towards common goals more effectively; and finally, the reflective process will allow teachers to become aware of the beliefs of their peers.

This last level of reflection is essential in that it helps us understand that many of the problems teachers face in the classrooms are not restricted to their classrooms in particular. Actually, much of their practice is socially constructed. Being aware of that enables them to work effectively towards actively shaping their own reality. In short, awareness of social aspects should never be underestimated, since it can be a powerful source of social change.

\section{Theoretical scope}

In the 1970's, Applied Linguistics research was focused on successful learners, in an attempt to identify what would differentiate them from the other type of learner. In the 1980's and 1990's, researchers tried to elaborate a taxonomy for learning strategies used by these students. However, recent studies have turned their attention to students' beliefs about the learning process, as they perceive it is important to understand what motivates the student to adopt certain strategies apart from simply identifying these learning strategies.

Meanwhile, in the mid-1960's and in the beginning of the 1970's, research on foreign language learning autonomy gathered strength and the first language labs and systems of self-access were created. At first, it was established that the language laboratories did not succeed because of the lack of specific training to learners. Training programs were then created. However, according to Gremmo and Riley (1995), for many years training programs were developed by people with no real interest in 
self-directed learning. But nowadays most of the authors have come to value students' work that present a certain degree of autonomy.

More recently, several works have come to establish that autonomy can be associated with motivation and, thus, become another reason to find ways to make students more autonomous. On the other hand, Coterall (1995) stressed the importance of analyzing students' beliefs as a cornerstone to developing any effort to increase their autonomy. In this way, the correlation between beliefs, autonomy and motivation and its impact over learners' awareness processes is established. Students that are conscious of their role in the learning process tend to be more autonomous and consequently more motivated to become fully engaged in the process of teaching/learning, and thus, have better chances to succeed.

\section{Methodological reflections}

Although we acknowledge the merit of more observational research methods which interfere less in the reality of the subject, in order to gather data on students' and teachers' perceptions about the teaching/learning process of English, we have chosen to make use of a controlled method of data collection, the questionnaires.

We started with a pilot study in the months of March and April of 1999 so as to verify empirically the theoretical reflections developed above and to guarantee the avoidance of errors of conception, which are very common in a research of this nature. In spite of the blatant limitations of the pilot project, we believe it served the purpose of constituting a basis upon which we outlined our area of interest and thoroughly tested our data collection tool.

\section{The questionnaires}

Through investigative reading and informal talks with teachers (personally or through the internet) on the results obtained in the pilot project, we were made aware of the gap between what teachers expected to be the answers from students and the answers they actually received. This is true even if the small size of the sample of the pilot project is taken under consideration. Because of a clear difference of opinion between teachers and students, we decided to work with a 
broader range of subjects, researching students and teachers alike, so that we could gain access to the beliefs of both.

Besides, in our study of beliefs, Applied Linguistics theory pointed towards the interest of having a more autonomous student. Informal conversations with some teachers also served to make clear their dissatisfaction with students' attitudes, which they considered excessively dependent. We decided, in the face of all that, to investigate motivation, which we had previously rejected, and autonomy.

As in the pilot project, we made use of BALLI questionnaires developed by Horwitz (1985). It is important to highlight that Horwitz came to the final questionnaires after extensive data collection from language students and teachers. She developed two different questionnaires: one for students and another for teachers, in order to identify their beliefs in relation to the difficulties of language learning, the aptitude for language learning, the nature of language learning, communication and language learning strategies, and learner motivation and expectations.

However, in order to adapt such questionnaires to our context, we decided to replace questions we considered less pertinent to the objectives of this research for questions referring to autonomy and power structures in the classroom, aspects that we considered of extreme importance, as mentioned in the beginning of this article. Therefore, we tried once again to ask teachers for their opinions on autonomy in the classroom. The opinions were collected personally and through the internet in a systematic way. Teachers were asked to write about autonomy vs. authoritarian practices in the classroom. The testimonies were compiled and used to choose the statements to be considered. Other statements were selected from the inventory elaborated by Coterall on the themes of beliefs and autonomy.

Besides these changes, as some people had problems answering certain questions when filling in the questionnaire of the pilot project, we rephrased some of the statements from Horwitz's questionnaire for clarification. Thus, sentences inserted in the questionnaire were chosen from a re-elaboration of statements in Horwitz' questionnaire, teachers' testimonies and the questionnaire developed by Coterall.

This way we have come to our final questionnaires that we expect may contribute to new research in the field. The teachers' questionnaire is similar to the students' questionnaire but for some adaptations that have been made. 


\section{Methodological proposal}

\section{Subjects and data collection}

The choice of schools where the research was to be conducted involved a series of decisions, amongst them whether we should work with private or public schools directly. Due to our political stance in this work, we decided it should focus on the public school system. Besides the commitment of this university (Federal University of Minas Gerais Brazil) to public education, the scope of the county system is wide enough so as to represent the heterogeneous character of our culture and its different social classes. It is also important to mention that data collection in the county system would be comparatively more viable than in the state system in terms of time and resources available for this research.

The next decision to be made was in relation to which schools we would use. According to the county education secretary, Belo Horizonte country is divided in nine administrative regions: Barreiro, Centro-sul, Leste, Nordeste, Noroeste, Norte, Oeste, Pampulha, and Venda Nova. We chose to work with the biggest school in terms of number of students of each region. All of them offer English classes and have a considerable number of teachers who could be interviewed. Then, in order to broaden our sample of teachers and assure a sample that would take into consideration the likely differences in profile of students and teachers in different locations within the same region, we decided to add a second school in each region to our sample. The criteria for choosing the second school in each region was the existence of "third cycle" (similar to high school) because it is in the third cycle that English classes start to be taught.

Data collection lasted two months and was no easy task due to the distance between schools and to the difficult access to some of them. Such problems were aggravated when we had to visit schools at night. We tried to encompass all shifts, but many times the teachers themselves would call our attention to the dangers of visiting those schools at that time. Besides, we faced the problem of finding people who would be in the school during the different shifts when English was taught, who were willing to hand out the questionnaires, explain their importance to the teachers, and collect them later. But such difficulties were overcome by repeated visits (at least 3 to each of the 18 schools). 
We believe the distance between schools, the difficult access and the lack of integration between shifts were not the only causes of the difficulties we had. Maybe we, as researchers, should ask ourselves if so many visits were not necessary because of the discredit of academic research by the public in general. Perhaps the teachers did not believe the results would be translated into actual changes. In the case of this research, it was up to the researcher to go to the schools on many different occasions. We had to talk with each teacher and, many times, wait for the breaks for the questionnaires to be filled out. Very often it was not possible to count on the good will and understanding of the people involved. Of course, we must not forget that this was not the general rule and that sometimes people were willing to help. Some of them indeed have shown interest in having access to the results of this research (which we were ready to share). In spite of the difficulties in the data collecting process itself, the results we obtained were rich and gratifying, making us believe that research can really take us to conclusions that will allow practical changes.

Each English teacher in every school was asked to answer the teacher's questionnaire and to request three of their students to fill out the student's questionnaires. As it was done in the pilot project, the questionnaires given to students and teachers were in Portuguese so that we could make sure all items were fully understood (since all the students and teachers interviewed spoke Portuguese as their native language).

Two hundred and fifty-five questionnaires were distributed among students and eighty-five among teachers, making up a total of three hundred and forty questionnaires in eighteen schools. We got one hundred and eighty-eight questionnaires back from students and seventy-four from teachers, which means a rate of approximately $73 \%$ and $87 \%$, respectively.

\section{Summary of the beliefs identified in the research}

Once the questionnaires were filled out, we expected the data collected to allow us to identify teachers' and students' beliefs in five categories of analyses:

- Aptitude to language learning: we intended to analyze questions such as whether interviewees (students and teachers) believe or not in the need for special skills to learn a foreign language, what they 
believe a learner needs to succeed and how they see students as learners;

- Level of difficulty of the language: concerned interviewees' beliefs about English as a foreign language, how difficult they find it and their expectations to learn it.

- Nature of language learning: this had to do with the importance interviewees give to cultural contact and exchange in the effective learning of a foreign language, and also if the students understand language learning as being different from other kinds of learning.

- Learning strategies: we intended to verify how important interviewees think spontaneous conversation is, learning strategies they usually use, oral practice and how students feel whenever they make use of them.

- Finally, under level of autonomy and motivation, we tried to measure how independent students are, and what the role of the teacher and of feedback is in the learning process, related to autonomy and motivation.

\section{Beliefs identified in the group of students}

On aptitude to language learning:

- $89 \%$ believe everybody is able to learn a language;

- $84 \%$ believe special skills are required in order to learn a language;

- $84 \%$ believe they are good language learners;

- 63\% believe some people are (born) more skilled to learn a language than others;

- 64\% believe Brazilians are good language learners.

On the level of difficulty of the language:

- $98 \%$ believe they will succeed in the learning of English;

- $76 \%$ believe English is an easy language to be learnt. Most of them think that if they study one hour a day every day, it will take them at most 5 years to learn it;

On the nature of language learning:

- $95.5 \%$ believe language learning has to do, basically, with learning grammar rules; 
- $71 \%$ believe it is important to learn about the culture of the country;

- $55 \%$ believe the best way to learn English is by spending some time in an English-speaking country;

On learning strategies:

- $97 \%$ seem to like traditional learning strategies, such as the ones used in audio lingual and behaviorist methods;

- 90\% value free conversation and 94\% give much importance to good pronunciation;

- Students seem to be aware of learning strategies: 68\% like to practice with native speakers whenever they have the chance to. In addition, $61 \%$ think it is worth guessing a word even if they are not sure it is the most appropriate in that context.

- Although aware of learning strategies, students do not feel very comfortable in using some of them: $56 \%$ believe they should not say anything unless they are sure that is the right way to say it and 52.5\% feel embarrassed when having to speak English.

On the level of autonomy and motivation:

- $90 \%$ believe they do well in other subjects at school;

- $87 \%$ think they know what they need English for;

- $96 \%$ think the teacher plays a central role in the learning process and that it is impossible to succeed without a teacher;

- 96\% seem to prefer paternalistic teachers: 93\% like the teacher to tell them what their difficulties are: $82 \%$ like the teacher to tell them what to do; $85 \%$ need the teacher to tell them how well they are progressing;

- $83 \%$ like to be tested regularly;

- $96 \%$ think it is important to have some kind of feedback;

- $76 \%$ believe to be ready to set their own goals and pinpoint what aspects of their English need to be improved;

- $70 \%$ believe it is desirable to have their own way to assess what has been learned;

- Most of them seem not to be ready to take the risks involved in learning a foreign language: $52 \%$ like to try out new activities in class; $51 \%$ like to study alone and $47 \%$ like to look for solutions for their own problems;

- $55 \%$ believe they know how to study a foreign language; 


\section{Beliefs identified in the group of teachers}

On aptitude to language learning:

- $85 \%$ believe everybody is able to learn a language;

- $81 \%$ believe some people are (born) more skilled to learn a language than others;

- Teachers seem to have a clear notion of what it takes to be a good language learner: $97 \%$ believe it is easier for children than for adults to learn a foreign language; $78 \%$ think it is easier for people who speak more than one language to learn a foreign language;

- 54.5\% believe Brazilians are good language learners.

- $57 \%$ believe their own students do not think they are good learners;

On the level of difficulty of the language:

- $28 \%$ believe they will succeed in the learning of English;

- $73 \%$ believe English is an easy language to learn. Most of them think that if they study one hour a day every day, it will take them at most 5 years to learn it;

On the nature of language learning:

- 96\% believe language learning has to do, basically, with learning grammar rules;

- $56 \%$ believe it is important to learn about the culture of the country as well;

- $70 \%$ believe the best way to learn English is by spending some time in an English-speaking country;

On learning strategies:

- Most of them seem to like traditional learning strategies, such as the ones used in audio lingual (99\%) and behaviorist methods (92\%);

- $100 \%$ value free conversation;

- Seem to be aware of learning strategies: 91,5\% like to practice with native speakers whenever they have the chance. $94 \%$ think it is worth guessing a word even if they are not sure it is the most appropriate one in that context. 
On level of autonomy and motivation:

- $66.5 \%$ believe their students do well in other subjects at school;

- $27 \%$ think students know why they need English;

- $89 \%$ think the teacher plays a central role in the learning process and that it is impossible to succeed without a teacher;

- most seem to be paternalistic to students: $74 \%$ think students like the teacher to tell them what their difficulties are: $94.5 \%$ think students like the teacher to tell them what to do; 100\% believe students need the teacher to tell them how well they are progressing;

- $84.5 \%$ think students like to be tested regularly;

- $100 \%$ think it is important to have some kind of feedback;

- $18 \%$ believe they are ready to set their own goals and pinpoint what aspect of their English needs to be improved;

- $70 \%$ believe they should have their own way in testing what has been learned;

- Most of them believe students are not ready to take the risks involved in learning a foreign language: $42 \%$ think students like to try out new activities in class; $5 \%$ think students like to study alone and $7 \%$ think students like to look for solutions to their own problems;

- 7\% believe they know how to study a foreign language;

\section{Conclusion}

We tried to focus the conclusion of this research on four main topics:

- Considerations on students' beliefs;

- Considerations on teachers' beliefs;

- Considerations on similarities and differences between teachers' and student's beliefs;

- Final considerations or suggestions.

In an effort to compose a broader picture of the beliefs identified in this research, we are going to mention other researches on the same subject conducted in Brazil. Our goal is not to focus exclusively on Brazilians, but on foreign language teaching instead of second language teaching, since we believe it is necessary to tell them apart. 


\section{Considerations on students' beliefs}

Students seem to believe in the idea of aptitude. As in Carvalho (2000, p. 80), we found that students believe "it is easier for children than for adults to learn a foreign language". They also believe "it is easier for someone who already speaks two languages to learn a third one". We tend to see these beliefs as being harmful to their learning, since most of the students of our sample are not little children and do not speak any other language besides Portuguese. However, the negative burden of these beliefs was counterbalanced by the fact that they see themselves as good language learners and they believe everybody can learn a foreign language.

Concerning English, the fact that students do not find it a difficult language seems to motivate them, and that is also a possible explanation for them to believe they will succeed in their learning. Students do not seem to feel anxiety or be afraid of such a task and that is positive. As Dalacorte (1999) suggests, these feelings are also directly related to their motivation to learn.

As in Barcelos (1995), we found that students of our sample also believe learning a language is basically a matter of learning language structure. We view this belief as harmful to the learning process once we see it is a result of a very narrow perception of language. Because of this, students may underestimate the task of learning English and, as a consequence, not devote enough time and effort to it.

Students believe the best way to learn English is by going to an English-speaking country. Considering that probably none of the students in our sample will have financial resources to travel abroad, it is important that some work be done on the possible ways to make up for this limitation.

The learning strategies identified seem to reflect students' beliefs that learning a language is basically a matter of learning its structure. They seem to overvalue repetition, oral practice and the use of tapes and videos. They also seem to place too much emphasis on pronunciation. Again, because of their limited opportunities to use the language, it may have as a consequence that they do not take advantage of their chances to speak because of being too self-conscious.

Finally, as seen above, students tend to view the teacher as being ultimately responsible for the learning process. As Barcelos (1995) 
detected, when so much importance is given to the teacher, the student does not see himself as co-responsible for the learning process. And as we believe learning, to a large extent, is a result of the direct involvement of the student in the course, it is essential that he also feels responsible for this process. Another possible negative consequence of such a view of the role of the teacher is that students tend to be very passive and not critical, since they believe the teacher is supposed to play these roles instead of them. As we have already mentioned, we believe a minimum level of autonomy is essential, not only because of the competitive society we live in, but also as a motivational tool, since more motivated students will probably study harder and have more chances of succeeding.

\section{Considerations on teachers' beliefs}

First of all, we would like to point out that we believe teachers' beliefs have repercussions on students because, as we found in the research, the latter tend to see teachers as a pattern to be followed.

Fortunately, teachers also believe everybody is able to learn a language. But teachers think it is easier for children than for adults to learn a foreign language and that it is easier for someone who already speaks two languages to learn a third one. Most of the beliefs identified seem to reflect the negative view teachers have on students. Only $7 \%$ of the teachers believe their students are good learners and that may end up affecting students' self-esteem, once they notice the ones they take for a model do not believe in their success.

As Paiva (1997) also found through the analyses of language programs in seven universities in the countryside of Minas Gerais, teachers tend to have a very narrow view of language, seeing it basically as a matter of habit formation. That belief may have as consequence the fact that teachers spend less time than they should preparing classes, since they think it is an easy task.

Once again, these beliefs above mentioned seem to reflect their view on the nature of language. Moita Lopes (1996, p. 40) states that "generally we still see nowadays a great emphasis on oral skill or, at least, a lot of repetition exercises for the sake of repetition." Such a stance was confirmed by our research, since more than $90 \%$ of the 
teachers consider repetition and oral drills (characteristic of audio lingual methodologies) very important. Thus, the strategies chosen led to the reinforcement of beliefs on the nature of language learning that we believe need to be reevaluated.

In regards to the language, they tend to believe English is not very difficult. This belief is positive, once it leads them to believe that English is something that can be taught and learned. On the other hand, teachers do not think their students will succeed, which is obviously a belief that is very damaging to the learning process. This is a factor for demotivation among teachers who tend not to dedicate themselves fully to their work, since they do not believe it can be very productive.

Finally, in regards to the level of autonomy of students, teachers seem to doubt students' capacity of being autonomous. As far as we can see, the most likely consequence is that teachers interact with students without expecting them to be autonomous and, worse, without letting them be autonomous.

Carvalho (2000) raises the hypothesis that teachers may feel threatened when they have to deal with a more autonomous student, or one who needs them less. This is an issue that deserves reflection. We think this belief is surely unfavorable to the learning process and therefore needs to be reevaluated.

\section{Considerations on the similarities and differences between students' and teachers' beliefs}

We were surprised when we realized such significant differences in students' and teachers' beliefs, as far as the students' self-image and the teachers' image of the students are concerned.

Referring to the categories that we wish to study so as to illustrate such conclusion, we realized that:

1) With regards to language-learning aptitude, both students and teachers support the idea of aptitude. Teachers seem to tend towards inatism, since the belief that language is easier for some people than others is stronger among them. A great number believe that it is easier for children than adults to learn a foreign language. However, both believe that everyone has potential to learn foreign languages. Finally, although the rate of agreement with the idea of aptitude varies, 
the majority of teachers and students agree and disagree with the same statements, except the one that refers specifically to them. Whereas the great majority of students (84\%) think they are better than the average as far as language learning is concerned, only $43 \%$ of the teachers think that their students consider themselves better than the others. In other words, although most of them agreed or disagreed with the same statements, their views on the students differ significantly.

2) Likewise, on the questions that identified teachers' and students' beliefs on the level of difficulty of the language, it was clear that both groups feel that English is an easy language, although the rates vary. Once again, however, they disagreed significantly with regards to the expectations in relation to the students. $86 \%$ of the students believe they will learn to speak English well, whereas only $28 \%$ of the teachers have the same expectation towards their students. In other word, within the category "level of difficulty of the language", teachers and students agree about the level of difficulty of the language and the time it takes to learn it. However, they disagree when it comes to how far students should be able to go on their own.

3) Still, on the nature of language learning, the majority in both groups agree in all the items investigated, except the ones that refer to the students. Although in different percentages, most of them seem to share the idea that a language is a system of rules, that it is necessary to know the culture of the country to speak that language well, that the best way of learning to speak a foreign language is to go to a country where it is spoken as first language and that learning a foreign language is quite different from learning other subjects. Likewise, the majority of both teachers and students disagree with the idea that people only get to speak a language well when they do not translate it. However, most of the students think they study English in the same way they study other subjects. The majority of teachers disagree with that. Once again, both groups seem to disagree when it comes to their view on the student.

4) About learning strategies, the majority of both students and teachers seem to agree on several items. Both, in their majority, agree that it is important to use English outside the classroom, that it is valid to "guess" when one is not sure which word is the most adequate, that good pronunciation is essential to learn English, that repeating and 
practicing orally is an important part of learning and that it is important to practice with tapes or videotapes. They also agree that the student feels inhibited when he has to speak English with other people. They disagree, however, with regards to the statement: "students should not say anything in English if they do not know how to say it correctly." Whereas a little more than half of the students agree with this (56\%), only $4 \%$ of the teachers do.

5) Finally, with regards to students' level of autonomy and motivation, beliefs referring to the role of the teacher and the role of feedback do not pose significant differences. Students as well as teachers agree that the teacher has a central role in the learning process. Both groups also agree that it is important that there is constant feedback throughout the course. On the other hand, they seem to disagree when it comes to the way students see the learning process. They disagree on student capacity to take on the goals of the course: $76 \%$ of the students agree and $82 \%$ of the teachers disagree that the students know which aspects they need to improve on. The same happens with regards to self-esteem. $90 \%$ of the students state that they know how to study for other subjects well, whereas only 33.5\% of the teachers share their opinion. In addition to that, $48 \%$ of the students believe they have been successful in learning English in previous experiences, and only $28 \%$ of the teachers agree with that. Thus, students and teachers do not share the same beliefs with regards to how students absorbed their previous experiences with the language. Likewise, they disagree on how they see the student at the present moment. The same can be said of students' capacity to take risks. If, on the one hand, $72 \%$ of the teachers think students avoid difficult things when they are studying, on the other hand, $64 \%$ of the students disagree with that. In this way, students think they are able to take risks, whereas teachers do not believe they are able to do so.

In short, the examples above seem to make it clear that students' and teachers' beliefs are relatively similar with regards to the nature of foreign languages, to its level of difficulty, to the notion of aptitude in foreign language learning and even to the learning strategies that should be used in class. Such data, indeed, make us think about a future inquiry into how much students' beliefs tend to reproduce teachers' beliefs. However, what we want to emphasize here is that, as far as how 
students see themselves as learners and how teachers see them, the beliefs were quite different.

We selected some items that clearly illustrate what we have just stated:

\begin{tabular}{|c|c|c|c|c|}
\hline \multirow[b]{2}{*}{ Data on students $\mathrm{x}$ teachers } & \multicolumn{2}{|c|}{ Stud. } & \multicolumn{2}{|c|}{ Teac. } \\
\hline & A & $\mathrm{D}$ & A & $\mathrm{D}$ \\
\hline \multicolumn{5}{|l|}{ I learn languages ___ . . My student thinks he learns languages___ $\ldots$} \\
\hline $\begin{array}{l}\text { (a) well above the average; (b) better than the average; } \\
\text { (c) worse than the average; (d) well bellow the average }\end{array}$ & 84 & 16 & 43 & 57 \\
\hline $\begin{array}{l}\text { I think I will learn to speak English very well. / } \\
\text { I think my students will learn... }\end{array}$ & 86 & 14 & 28 & 72 \\
\hline $\begin{array}{l}\text { I think I will come to speak English well. / } \\
\text { My students think they will come ... }\end{array}$ & 98 & 2 & 51 & 49 \\
\hline $\begin{array}{l}\text { I study English the same way I study other subjects. } \\
\text { / My students study English... }\end{array}$ & 59 & 41 & 33,5 & 66,5 \\
\hline We should not say anything in English unless we are sure it is correct. & 56 & 44 & 4 & 96 \\
\hline $\begin{array}{l}\text { I feel intimidated when I speak English to other people. / } \\
\text { My students feel ... }\end{array}$ & 52,5 & 47,5 & 92 & 8 \\
\hline I know exactly what I need English for. / My students know exactly ... & 86,5 & 13,5 & 27 & 73 \\
\hline $\begin{array}{l}\text { I know what aspects of my English have to be improved. / } \\
\text { My students know what aspects ... } \\
\text { (a) always; (b) generally; (c) sometimes; (d) never }\end{array}$ & 76 & 24 & 18 & 82 \\
\hline $\begin{array}{l}\text { I usually check on what I write looking for mistakes. / } \\
\text { My students usually check on what they write... } \\
\text { (a) always; (b) generally; (c) sometimes; (d) never }\end{array}$ & 69 & 31 & 24,5 & 75,5 \\
\hline $\begin{array}{l}\text { I like to try to solve my language problems on my own. / } \\
\text { My students like ... }\end{array}$ & 47 & 53 & 7 & 93 \\
\hline $\begin{array}{l}\text { I have my own way to test how much I learned. / } \\
\text { My students have their own way... }\end{array}$ & 70 & 30 & 41 & 59 \\
\hline $\begin{array}{l}\text { In the past I was a good language learner. / } \\
\text { In the past my students were ... }\end{array}$ & 48 & 52 & 28,5 & 71,5 \\
\hline $\begin{array}{l}\text { I need the teacher to tell me how I am progressing. / } \\
\text { My students need me to tell them... }\end{array}$ & 85 & 15 & 100 & 0 \\
\hline I avoid difficult things when I am studying. / my students avoid ... & 36 & 64 & 71,5 & 28,5 \\
\hline I know what to do to study English. / My students know what to do to ... & 55 & 45 & 7 & 93 \\
\hline I can study other subjects well. / My students study other subjects well. & 90 & 10 & 33,5 & 66,5 \\
\hline
\end{tabular}

$\mathrm{A}=\mathrm{TA}+\mathrm{A}$ (Totally agree + agree $)$

$\mathrm{D}=\mathrm{TD}+\mathrm{D}$ (Totally disagree + disagree $)$

We believe that the data we gathered has shown a lack of awareness and reflection on both parts in regards to the differences in 
their beliefs. We hope this work has contributed to raise questions about the teaching/learning process. As already mentioned, we do not wish to suggest that a given group's beliefs should be imposed upon or substituted by the beliefs of another group. On the center of our concerns is the fact that teachers see students in such a negative way, as individuals unable to establish goals, take risks, and succeed in studying English. We established likely consequences of these beliefs, but we think it is also important (and riskier) to raise a hypothesis as to how teachers have come to them.

Considering that teachers' beliefs about students are negative to the learning process, we tried to reflect upon the reasons that led teachers to have opinions that are so different from those of their own students and yet so negative.

According to the teachers, the students are not successful because:

- They do not study enough. This stance is in accordance to students' and teachers' beliefs about the nature of the language. It is possible that the students, unaware of the complexity involved in language learning, dedicate actually less time and effort than they were expected to.

- The course is structured in a way that leaves insufficient course work time. Actually, in some informal conversation with teachers as questionnaires were filled out, several of them said the course work time is quite small, perhaps even insufficient for students to learn the language. Paiva (1997) also found that high school teachers believe the course work time destined to English classes is too short, something that made them feel even discriminated against.

- Teachers themselves have low self-esteem and transfer that to the students, thinking they cannot succeed. But why would teachers have low self-esteem? We believe that the simple fact that they work in public county schools getting paid less than their peers in the private sector makes them think they are inferior in relation to the latter. Besides, several authors have discussed the issue of the nonnative teacher. If, according to Horwitz (1987), the differences between native and non-native teachers should not be ignored, we agree with Liu (1999) that, since it is impossible to ignore the complexity of this issue, we should strive for increasing the skills of 
professionals in language learning in general, whether they are native or not. Peter Medgyes in his "The non-native teacher" (1994) dedicates a chapter to a comparison between native and non-native teachers. Although his research did not show that teachers or professionals in the area recognize native teachers as being better, directors of schools in England tend to reject non-native teachers since native speakers "are more valuable merchandize according to the public" and "have a better commercial appeal". Such preferences have been influenced by legislation changes, and hiring a teacher solely based on his or her being a native speaker has been seen as discrimination. However, the general public seems to believe that native teachers are better than non-native teachers. Such belief may also be the result of teaching theories that were fashionable for some time and that, when approaching the issue of meaningful input, had to cope with the lack of spontaneity of activities carried out in class and even of the use of a second language between teachers and students when they share the same first language. The importance, however, is that this can be an additional frustration for a non-native teacher who works in the schools with which we worked. Other facts were brought to discussion by Paiva (1997), such as the fact that teachers teach a language that they do not speak natively and that they cannot practice and the course work time that is insufficient and is understood as a sign of their little value.

- Teachers do not seem to expect much from students. This may be a vicious circle since teachers do not believe students are able to have a good performance and prepare their courses based on tasks that are of low level of difficulty. Because of that, students think the course is easy and thus, expect to be successful. This would explain the discrepancies between students' and teachers' expectations during the course.

\section{Final considerations}

How can a discussion about students' and teachers' beliefs lead to changes in this process? We would like this work to be understood as an invitation for a reflection about our attitudes as educators and the attitudes of the students with whom we interact. Because we think that our beliefs 
are the base of what we are and think, we would like to suggest that this discussion be taken to the classroom. It is only when these beliefs are discussed among teachers and students actually engaged in the practice of teaching and learning English that we may be able to verify the implications of each belief and its base in each specific context.

We believe there is much to be done. Besides classroom discussion, other academic work has to be developed not only to identify other beliefs but also to uncover the reasons why people have such beliefs at a given moment and ultimately, finding more effective ways of dealing with them.

\section{Bibliographic references}

BARCELOS, A. M. F. A cultura de aprender lingua estrangeira (inglês) de alunos formados em Letras. 1995. Dissertação (Mestrado) - UNICAMP, Campinas. (Inédita)

CARVALHO, V.C.P.S. A aprendizagem de lingua estrangeira sob a ótica de alunos de Letras: crenças e mitos. 2000. Dissertação (Mestrado) UFMG, Belo Horizonte. (Inédita)

COTERALL, S. Readiness for autonomy: investigating learner beliefs. System v. 23, n. 2, p. 195-205, 1995.

DALACORTE, M.C.F. A participação dos aprendizes na interação em sala de aula de inglês: um estudo de caso. 1999. Tese (Doutorado) UFMG, Belo Horizonte. (Inédita).

GREMMO, M.-J.; RILEY, P. Autonomy, self-direction and access in language teaching and learning: the history of an idea. System, v. 23, n. 2, p. 151-164, 1995.

HORWITZ, E.K. Using student beliefs about language learning and teaching in the foreign school method's course. Foreign language annals, v. 18, n.4, p.333-340, 1985.

HORWITZ, E.K. Surveying student beliefs about language learning. In: WENDEN, A. et al. Learner strategies in language learning. New York: Prentice Hall. 1987. p. 119-129.

LIU, J. Non-native English speaking professionals in TESOL. TESOL Quarterly, v. 33, n. 1, p. 85-101, 1999. 
MEDGYES, P. The non-native teacher. London: MEP Monographs, 1994. MOITA LOPES, L.P. Oficina de lingüistica aplicada: a natureza social e educacional dos processos de ensino/aprendizagem de línguas. Campinas: Mercado de Letras, 1996.

PAIVA, V.L.M.O.; VIEIRA-ABRAHÃO, M. H.; LEFFA, V. J. Repensando o curso de letras: habilitação em língua estrangeira. Anais da 49 ${ }^{\underline{a}}$ Reunião Anual da SBPC. 1997, p. 266-272.

PAIVA, V.L.M.O. A identidade do professor de inglês. Revista da APLIEMGE, v. 1. p. 9-17, 1997. 